\title{
THE EFFECT OF GROUP EDUCATION USING ONLINE MEDIA ON SELF CARE ON OBESITY STUDENTS AT THE FACULTY OF NURSING MUHAMMADIYAH UNIVERSITY JAKARTA 2021
}

\author{
Fitrian Rayasari ${ }^{1^{*}}$, Dhea Ananda Nur Afifah ${ }^{2}$ \\ 1. Faculty of Nursing, Muhammadiyah University of Jakarta, Jakarta-Indonesia \\ 2. Faculty of Nursing, Muhammadiyah University of Jakarta, Jakarta-Indonesia
}

*Correspondence: Dhea Ananda Nur Afifah | Muhammadiyah University of Jakarta | deaananda78@ gmail.com

\begin{abstract}
Introduction: Obesity in young adults can cause various health problems, including in the long term it will cause complications of diseases such as hypertension, diabetes mellitus and death at a young age. Self care in obesity is a management consisting of diet processing, physical activity, modification of life attitude (behavior therapy) and medical therapy. Peer group education is a method that helps increase understanding and self-care for obese students. The purpose of this study was to determine the peer group education method to increase self-care of obese students.

Method: The research design used was a quasi-experimental pre and post test, with a dependent t-test. Collecting data using the Diabetes Self Management Questionnaire (DMSQ). Sample of 30 respondents.

Results: The results of this study obtained that there was an effect of peer group education on increasing the self-care value of obese students ( $\mathrm{p}$-value $=0.00)$.

Conclusion: Suggestions from this study are self-care is one of the efforts that can be used to overcome the problem of obesity at a young age. Educational institutions can implement self-care through healthy exercise programs every morning or health education programs in health services.
\end{abstract}

Keywords: Obesity student, Self care, Peer group education method.

Received November 29, 2021; Accepted December 30, 2021

\section{INTRODUCTION}

Obesity or overweight can be interpreted as an excessive accumulation of body fat tissue which has an adverse effect on health which will lead to various complications of disease in the future (WHO, 2017). A person can be classified as obese by measuring using the Body Mass Index (BMI). Underweight with a body mass index of less than $\left(18.50 \mathrm{Kg} / \mathrm{m}^{2}\right)$, normal weight with a body index mass of $\left(18.50-24.99 \mathrm{Kg} / \mathrm{m}^{2}\right)$, overweight or obese with a body mass index of $\left(25-29.99 \mathrm{Kg} / \mathrm{m}^{2}\right)$, obesity class 1 with a body mass index of $\left(30-43.99 \mathrm{Kg} / \mathrm{m}^{2}\right)$, obesity class 2 with a body mass index of $\left(35-39.99 \mathrm{Kg} / \mathrm{m}^{2}\right)$ and obesity class 3 with a mass index body of more than $\left(40 \mathrm{Kg} / \mathrm{m}^{2}\right)$ (Joan, 2014).

Obesity is currently caused by many factors, one of which is a factor that cannot be changed, namely genetics. According to Kurdanti (2015) that a person is obese, namely someone who tends to have parents who are obese compared to someone with parents who have normal weight. Another factor besides genetic factors that can be changed is lifestyle. The lifestyle referred to as the cause of obesity is an unhealthy diet, one of which is junk food or overeating. Junk food is Fast food that is high in calories and low in fiber. In addition, junk food is harmful to health if consumed in excess (Ministry of Health, 2018). According to Kristiana (2020) junk food is very popular among teenagers or young adults because nowadays there are more and more restaurants that provide junk food. When food is consumed in excess, it is stored in adipose tissue. Another factor or second factor that can cause obesity is a lack of physical activity such as exercise. Physical activity according to WHO (2018) is the movement of limbs assisted by skeletal muscles that require energy such as household chores, walking and others. According to Widianti et al (2014) someone who does moderate or heavy activity has a lower risk of becoming obese.

Currently, the prevalence of obesity, especially in adolescents or young adults worldwide, is still high. The prevalence of overweight (obesity) that occurs in the world globally has become an epidemic. As many as 300 million adults are obese, with at least 2.8 million people dying each year from obesity (WHO, 2017). Obesity is also associated with high-income countries. In addition, obesity also occurs in middle to low income countries (Hermawan, 2020). In the UK (17-26\%) the population suffers from obesity (Kusoy et al 2013). Meanwhile, in developing countries, Indonesia, the prevalence of obesity has increased in the 
last 3 years as much as 5\%. According to Research of Basic Health (Riskesdas) in 2018 showed that the proportion of central obesity was $31 \%$, an increase from the proportion of obesity in 2013 which was $26 \%$. Meanwhile, according to the Non-Communicable Diseases Section (PTM) there are 43,792 obese people in the capital city of Jakarta. A total of 27,463 of them are women and 16,329 are men (DKI Jakarta Health Office, 2017).

Cases of obesity that continue to increase if left unchecked and there is no effort in handling the problem of obesity, especially in adolescents or young adults will cause various degenerative diseases such as heart disease, hypertension, diabetes mellitus and respiratory diseases such as asthma. In addition to obesity can cause physical problems, obesity can also have an impact on the psychological. Because many studies report cases of low self-esteem and depression in obese patients. This happens because teenagers or young adults who are obese will be made a laughing stock or even ridiculed by their peers. Obesity can also lead to a tendency to depression because at the time of puberty, teenagers or adults, Efforts to overcome obesity can be done with various activities including dietary regulation, activity regulation, medication and surgery. This activity can be done by him as an effort to overcome the health problems experienced, called self care.

Self care is self-care that a person can do independently (WHO, 2014). Self care in the management of obesity consists of physical activity, diet management, medication and behavior therapy. Self care in obesity is related to basic conditioning factors, including gender, knowledge, age, environmental factors, lifestyle, and motivation (Parellangi, 2018 and Siokal et al, 2017). Self care in an obese person can be measured using The Institute for Functional Medicine and the modified Diabetes Self Management Questionnaire (DSNQ) (Adelia, 2020). The benefits of implementing self care for obesity are that it can reduce stress, regulate and improve mental health and overcome and prevent those that can affect physical health (Pranjaya and Nina, 2020). A person's self care can be achieved by increasing knowledge. This is in line with Adelia's research (2020) that one of the factors related to self-care is knowledge. Knowledge can change someone who is obese to live a healthy life, eat well and exercise regularly so that if this happens consistently, a person's weight with obesity will decrease. Knowledge can be obtained by reading books, seeking information or by education. regulate and improve mental self and overcome and prevent that can affect physical health (Pranjaya and Nina, 2020). A person's self care can be achieved by increasing knowledge. This is in line with Adelia's research (2020) that one of the factors related to self-care is knowledge. Knowledge can change a person who is obese to live a healthy life, eat well and exercise regularly so that if this happens consistently, a person's weight with obesity will decrease.

Knowledge can be obtained by reading books, seeking information or by education. regulate and improve mental self and overcome and prevent that can affect physical health (Pranjaya and Nina, 2020). A person's self care can be achieved by increasing knowledge. This is in line with Adelia's research (2020) that one of the factors related to self-care is knowledge. Knowledge can change a person who is obese to live a healthy life, eat well and exercise regularly so that if this happens consistently, a person's weight with obesity will decrease. Knowledge can be obtained by reading books, seeking information or by education. This is in line with Adelia's research (2020) that one of the factors related to self-care is knowledge. Knowledge can change a person who is obese to live a healthy life, eat well and exercise regularly so that if this happens consistently, a person's weight with obesity will decrease. Knowledge can be obtained by reading books, seeking information or by education. This is in line with Adelia's research (2020) that one of the factors related to self-care is knowledge. Knowledge can change someone who is obese to live a healthy life, eat well and exercise regularly so that if this happens consistently, a person's weight with obesity will decrease. Knowledge can be obtained by reading books, seeking information or by education.

Education is information given to a person for behavior change, behavior development, social change and physical change for his health by means of persuasion, persuasion, appeal, providing information, invitations, providing awareness and so on. (Notoatmodjo, 2012). Education can be done by various methods, one of which is the peer group method, namely peer groups are teenagers who have approximately the same age or maturity level and interact with each other and have a unique role in culture or habits (Santosa, 2010). The benefits of the peer group method are very effective in overcoming problems in adolescents because the explanation given by a group member will be easier to understand and communicate openly (Pawelloi, et al 2010). According to Astika's research (2017), it was found that peer group education is effective in increasing knowledge and behavior of balanced nutrition. This statement is 
reinforced by research by Mohammad (2018) that there are significant differences in physical activity, weight loss and a decrease in body fat percentage using the peer group method.

The delivery of education requires tools or media that are useful for conveying materials or messages by the officers of the target group of education. Educational media consist of words, writings, radio recordings, films, television, field trips, demonstrations and original objects (Notoatmodjo, 2012). Currently, during the Covid-19 pandemic, gathering activities risk the spread of the virus. Therefore, online media is very influential and widely used. Health education can be done using a smartphone or using various social media (instagram, whatsapp, twitter, zoom meeting, microsoft team and facebook). According to Kim and Kyongsan (2019), using a smartphone that contains guidelines for physical activity, diet and health management has been proven to be able to increase physical activity and lose weight in respondents.

The Faculty of Nursing, Muhammadiyah University Jakarta is one of the health faculties located in DKI Jakarta with 745 regular undergraduate students. As prospective health workers, of course, health students have a role as role models in carrying out nursing care. Research conducted by Mahdiyah (2020) found that 30\% of the 274 (94 students) of the Faculty of Nursing, Muhammadiyah University, Jakarta, were obese. According to Mahdiyah's research (2020) it was found that the factors that affect obesity that occur in students of the Faculty of Nursing, Muhammadiyah University, Jakarta, are poor eating patterns in 274 obese students by 107 (73.8\%), physical activity that is not new by 55 respondents $(42.6 \%)$, factor genetics by 65 respondents (48.9\%) and emotional patterns by 53 respondents (43.8\%). This research was continued by Adelia (2020) who examined self-care in obese students, from 86 respondents pre-obesity and obesity were found to have less self-care with a total of $48(62.8 \%)$. The influencing factors in Adelia's research (2020) are age, pattern life, de velopment, gender, environmental status, motivation and knowledge. In Adelia's research (2020) as many as (33.3\%) of 86 students who have less knowledge to do self- care or self-care. The results of researcher interviews with 10 final semester students at the Faculty of Nursing, Muhammadiyah University, Jakarta who are obese, still lack self-care or Self Care as evidenced from 10 students, 6 of whom often consume junk food (instant noodles, KFC, Mcd, fried foods and others). ) on lecture days (Monday- Friday) when skipping breakfast and low physical activity due to a solid recovery. However, students said they did not know when eating junk food to replace breakfast continuously and not doing exercise would lead to weight gain. This statement is reinforced by Dewi's research (2018) that the proportion of obesity is higher in adolescents who often consume junk food as much as 1- 4 times or consume 500-1000 calories a day which is 64\% compared to adolescents who do not consume junk food $36.9 \%$ ). Thus self-care or self-care for obese students is still lacking. To overcome the problem of obesity that occurs in students, it is necessary to have the ability to take care of themselves or self-care and this can This statement is reinforced by Dewi's research (2018) that the proportion of obesity is higher in adolescents who often consume junk food as much as 1-4 times or consume 500-1000 calories a day which is $64 \%$ compared to adolescents who do not consume junk food 36.9\%). Thus self-care or self-care for obese students is still lacking.

To overcome the problem of obesity that occurs in students, it is necessary to have the ability to take care of themselves or self-care and this can This statement is reinforced by Dewi's research (2018) that the proportion of obesity is higher in adolescents who often consume junk food as much as 1-4 times or consume 500-1000 calories a day (64\%) compared to adolescents who do not consume junk food 36.9\%). Thus self-care or self-care for obese students is still lacking. To overcome the problem of obesity that occurs in students, it is necessary to have the ability to take care of themselves or self-care and this can one of them is using peer group education.

\section{METHOD}

This study uses a quast experimental design in the form of a one-group pretest- posttest, where the researcher only performs an action or intervention in a group without a comparison. To assess the success of this design, a comparison of the post-test and pre-test scores was used (Dharma, 2011). A pre-test was conducted on the respondent group to determine the initial value of self-care for obese students. The post test was carried out again to determine the final score on obesity student self care. The intervention was carried out using online media, namely zoom meeting and whatsapp group. Then a post test was conducted to determine the final score of the respondent's self-care behavior. Then the value of the results before and 
after the intervention will be compared.

\section{RESULTS}

Characteristics of Respondents (gender and age)

Table 1. Frequency Distribution of Respondents Characteristics of Respondents ( $\mathrm{n}=30$ )

\begin{tabular}{ccc}
\hline Gender & Frequency Respondent & Percentage (\%) \\
\hline Man & 5 & 16.7 \\
Woman & 25 & 83.3 \\
Total & 30 & 100.0 \\
\hline
\end{tabular}

Based on Table 5.1, it can be seen that the majority of respondents at the Faculty of Nursing, Muhammadiyah University, Jakarta are female, as many as 25 people (83.3\%) and respondents men as many as 5 people $(16.7 \%)$.

\section{Age Frequency Distribution of Respondents}

Table 2 Age Frequency Distribution $(\mathrm{n}=30)$

\begin{tabular}{ccccc}
\hline Information & mean & SD & Minimum-Maximum & 95\% CI \\
\hline Age & 21.2 & 1,533 & $18-25$ & 20.59 \\
\hline
\end{tabular}

Based on table 5.2, it is found that the average age of respondents in the students of the Faculty of Nursing, Muhammadiyah University, Jakarta, is 21.2 years, with a standard deviation of 1.533 years. The youngest student is 18 years old and the oldest is 25 years old. The results of the analysis can be concluded that $96 \%$ believe that the average age of students is between 20.6 years to 21.8 years.

\section{Distribution of the Average Frequency Distribution of Self Care Pre and Post Test Respondents}

Table 3. Frequency Distribution Mean self care score $(\mathrm{n}=30)$

\begin{tabular}{ccccc}
\hline Variable & mean & SD & Minimum- Maximum & 95\% CI \\
\hline before self care & 29.57 & 5.82 & $18-40$ & $27.40-31.74$ \\
after self care & 44.17 & 6.99 & $27-55$ & $41.56-46.78$ \\
\hline
\end{tabular}

The results of the analysis showed that the average self-care score before 29.57 (95\% CI: $27.40-$ 31.74 ) with a standard deviation 5.82 with the lowest score of 18 and the highest score of 40 . From the results of the interval estimation it can be concluded that $95 \%$ is believed that the average is 27.40 to 31.74 . Average score of self care after education 44.17 (95\% CI 41.56 - 46.78) with a standard deviation of 6.99 with the lowest score of 27 and with the highest score 55. From the results of the interval estimation, it can be concluded that it is $95 \%$ believed that the mean is 41.56 to 46.78 .

\section{Frequency Distribution of Respondents Frequency Distribution Based on Dependent Variables}

Table 4 Distribution of Average Self Care According to the First and Second Measurements (n=30)

\begin{tabular}{cccccc}
\hline Variable & mean & Mean Differences & SD & P value & N \\
\hline before self care & 29.57 & & 5,811 & & \\
after self care & 44.17 & 14,600 & 6,993 & 0.0000 & 30 \\
& & & & \\
\hline
\end{tabular}

The average self-care in the first measurement is 29.57 in the second measurement, the average knowledge is 44.17. It can be seen that the mean difference between the first and second measurements is 14,600 with a standard deviation of 8,398 . The results of the statistical test obtained a value of $p=0.000$ 
$(<0.005)$, it can be concluded that there is a significant difference between the first self- care measurement and the second measurement. There is a significant difference before and after being given education using online media.

\section{DISCUSSION}

\section{Characteristics Respondent Based on Gender}

Based on data from the results of research data shows that the most gender in this study were women as many as 25 people (83.3\%). That nurses up to this point more in interested by woman although the need for male nurses moment this very needed.Statement this in line with Mahdiyah 2020 research with samples study as much 272 respondents from the Faculty of Nursing UniversityMuhammdiyah Jakarta as many as 243 (89.3) are women. According to Intening 2018 in Milata (2019) which states that women have a gentle attitude so that they are suitable for nursing duties, with this statement, the majority of someone who interest in nursing are women. This statement is strengthened by research conducted by Syahputra with a research sample of S1 PSIK FK USU. Syahputra stated that the proportion of women in nursing education is indeed much higher than that of men. Because it is caused by a woman's personality which is identical to a person who is friendly, patient, painstaking, weak, gentle, compassionate and likes to socialize.

\section{Age}

Based on data from the results of research data shows that the youngest age is 18 years and the oldest is 25 years. From the results of the interval estimation, it can be concluded that it is $95 \%$ believed that the average age is 20.59 to 21.74 , namely entering young adulthood (productive age). According to data obtained from researchers via google form, the average age of nursing students University Muhammadiyah Jakarta $18-25$ years. This statement is in line with Adelia's research (2020) with a research sample of 93.0\% (80 respondents) students in Nursing at the University of Muhammadiyah Jakarta. Faculty Knowledge Nursing University Muhammadiyah Jakarta is 18-25 years old.

The age of students for the first strata (S1) generally ranges from 18-24 years. They are in late adolescence or are in both, namely the transition period from adolescence to adulthood (Hurlock 1980 in Nurhayati 2011). This statement is reinforced by research by Paramita 2010 Case Study of Differences in Student Characteristics of X-Indonesian University and Y-Australia University that the average undergraduate student in Indonesia is 18-24 years old. Early adulthood is a period of transition from adolescence to adulthood, which occurs in the late teens to 20 s and only ends around the age of 30 . (Santroko 2003 In Paramita 2010).

\section{The Effect of Peer Group Education on Increasing Self Care Ability in Obese Students at the Faculty of Nursing, Muhammadiyah University, Jakarta}

The results of this study obtained statistical test results with $p$-value $=0.00$ which means that there is a $5 \%$ difference in the average Self Care for Nursing students at Muhammadiyah University of Jakarta who are obese. With a self- care pre-test score of 29.57 and a post-test self-care score of 44.17, it is included in the good self-care category. This statement is supported by Schmit's 2013 research categorizing the value of self-care bad by $0-16$, enough 16-31 and good 31-48. The Peer Group method is a technique or method of teaching and delivering information to a group of the same age or maturity level in terms of interests, values, personality traits and opinions (Syamsu in Fatonah 2012). This method is done by discussing groups in which there are a maximum of 15 participants. In this study, the time taken for 7 days was used to measure self care for each respondent. The educational process carried out by researchers in the intervention group was a peer group, to solve the problem of self- care experienced by respondents so far, then the results of increasing self- care for obese students in intervention respondents. Through the results of this study, it is the basis that peer group education and special preparation for obese students in receiving health information is very important. This is done with the aim of more effective messages or information that will be received by students. The researcher assumes that students who are given health education and self-care guidelines in a structured, gradual and consistent way will change their lifestyle so that they can improve their health good self-care behavior.

The advantage of this Peer Group method is that it is effective in overcoming problems that occur in adults. Because the explanations contained in the group are easy to understand so that open communication 
is established (Pawelloi, et al 2010). This statement is in line with Ermi's research (2015) that the peer group discussion method for 4th week State Senior High School students can only increase knowledge on the material discussed or given. What is needed with the initial test is $25.71 \%$ to $31.39 \%$ after being given education using the peer group method.

\section{CONCLUSION}

The conclusion of this research:

1. The characteristics of the respondents concluded in this study were mostly female $(83.3 \%)$ with an average age of 21.2 years.

2. An increase in the average value of self care before and after the management of education from 29.57 to 44.17. The effect of increasing self-care scores on obese students with $p$ value $=0.00$ at the Faculty of Nursing University Muhammdiyah Jakarta so that it was found that there was an influence of peer group education using online media on self care for students at the Faculty of Science Nursing University Muhammadiyah Jakarta

The Suggestions:

1. For Educational Institutions

It is hoped that the results of this study can be used as material in the learning process about the importance of education health unique improve self care in obese students, especially in adolescents and young adults. In addition, educational institutions can also create programs such as special sports for students that are scheduled every week.

2. For Further Researchers

It is hoped that this can be done by adding other variables such as measuring weight and body mass index, education with brainstorming, the influence of counseling guidance, and others to keep students away from the effects of diseases caused by obesity and using peer group participation in overcoming obesity problems.

3. For Health Workers

It is expected to include the participation of health workers through motivational activities such as posting posters containing healthy living and consuming high-protein, low-fat foods to avoid obesity. In an effort to improve self-care in young adults

\section{REFERENCE}

Abdul, s. (2010). Risk Factors for Obesity in Adolescents. MKMI , 185-1990.

Adriani, W. (2016). Introduction to Community Nutrition. jakarta: KENCANA.

Bak. Marline, m. (2019). Dietary Strategies for Weight Loss Maintenance. nutrients.

Batacan, MV (2016). Effects of High Intensity Interval Tranning on Cardiometabolic Health : A Systematic Review and Meta- analysis of Intervention Studies.

Chau, m. L. (2020). The Use Of Social Media In Nutrition Intervention For Adolescents And Young Adults - A systematic review. HHS Public Access, 77-91.

Dahlan, s. (2010). Diagnostic Research. Jakarta: Sagung seto.

Goddess. ade, T. (2013). Relationship between diet, physical activity, attitudes, and knowledge about obesity with the nutritional status of civil servants at the East Java Provincial Health Office. Indonesian Nutrition Media, 42-48.

Eid, TB (2017). Effeitive Behavior Change Teacnique For Physical Activity and Helthy Eating In Overweight And Obese Adults; Systematic Review and Meta-Regression Analyses. International Journal Of Behavioral Nutrion And Physical Activity, 14- 42.

Ekadinata.Widyandana. (2017). Health promotion using images and text in the WhatsApp application for Posbindu cadres. Journal of Community Medicine and Public Health.

Endah, P. (2017). Improved Knowledge and Behavior of Balanced Nutrition Using Peer Education Methods. Faculty of Public Health, 114-120.

Erni, N. (2015). The Use of Discussion Methods to Improve Learning Outcomes of Social Change Materials for Class XII Students of SMA Negeri 4 Pekanbaru. HIGHLIGHT , 155-168.

Firdaus, m. (2017). Diabetes and Seaweed. poor: UB press.

Han Na Kim, KS (2019). Smartphone Based Health Program for Improving Physical Activity and Tackling 
Obesity for Young Adults: A Systemic Review and Meta-Analysis. international journal Environment Research and Public Health.

Haqien, R. (2020). Utilization of Zoom Meetings for the Learning Process During the Covid 19 Pandemic. Composition of Educational Articles, 60-61.

Hartono, d. A. (2014). Textbook of Nutrition Science Ed.4. Jakarta: EGC.

Hendra, f. (2016). Risk Factors for Obesity in Adolescents in Bitung City. biomedical .

Hermawan, D. (2020). Recognizing Obesity. Yogyakarta: ANDI.

Jaelani, M.A. (2018). The Effectiveness of Peer Group Activities on Weight Loss and Body Fat Percentage in Overweight Adolescents. Brawijaya Medicine, 127-132.

Joan webster, am (2014). Nutrition \& Dietetics.Jakarta: EGC.

Jones, A. b. (2007). Foresight Tackling Obesities. Future Choices Obesogenic.

Kristiana, DU (2020). The Relationship Between Sleep Patterns And Eating Habits Of Junk Food With The Incidence Of Obesity In Students Of The Malahayati Univrsiats In 2019. Human Care, 750-761.

Kurniawati, RF (2016). The Relationship Between Diet, Energy Intake, Physical Activity, And Sleep Duration With Obesity In Police. Indonesian Public Health Publication.

Kusoy. Karina, FB (2013). Obesity Prevalence in Adolescents in Minahasa Regency. Ebiomedicine, 981985.

Laksmi, P. (2020). The Monograph of Educational Supportive Programs Improving Self Care Ability in Heart Failure Patients. Yogyakarta: The Independent Heritage Star.

Lemon, p. (2015). Textbook of Medical and Surgical Nursing ed, 5 vol 2. jakarta: EGC.

Leonita E, J. (2018). The Role of Social Media in Health Promotion Efforts: Literature Review. Vocational and Technological Innovation .

Masrul. (2018). The Obesity Epidemic And Its Impact On The Public Health Status And The SocioEconomic Of The Nation. Andalas Medical Magazine, 152-162.

Notoatmodjo, s. (2012). Health Promotion and Health Behavior. Jakarta: PT Rineka Cipta.

Notoatmodjo, s. (2010). Health Promotion Theory and Applications Revised Edition 2010. Jakarta: Pt Rineka Cipta.

Permatasari, TA (2017). Improved Knowledge and Behavior of Balanced Nutrition Using Peer Education Methods. Faculty of Public Health, 114-120.

Pranjaya, Nina. (2020).The Concept of Self Care for Counselors During a Pandemic.Jurnal Guidance Islamic Counseling, 1

Rafiony. Ayu, MD (2015). Fast food and soft drink consumption as risk factors for obesity in adolescents. Indonesian Clinical Nutrition, 170- 178.

Rantung. Jeany, KT (2015). Relationship of Self Care with Quality of Life of Diabetes Mellitus (Dm) Patients at the Indonesian Diabetes Association (PERSADIA) Branch Cimahi. Nursing Scholastic.

Rayasari, a. (2020). Analysis of Factors Associated with Self Care in Pre- Obesity and Obesity Students at the Faculty of Nursing Universi tyMuhammadiyah Jakarta. 76.

Rayasari, M. (2020). Factors Associated with Obesity in Students Faculty Knowledge Nursing University Muhammadiyah Jakarta 2020. 63.

Sabarudin, m. R. (2020). The Effectiveness of Online Education Through Video and Leaflet Media on Prevention Knowledge Levels Covid-19 inBaubau City. Galentika pharmacy, 309-318.

Samdal, eb (2017). Effective Behavior Change Technique For Physical Activity and Healthy Eating In Overweight and Obese Adults ; Systematic Review and Meta- Regression Analyses. Behavior Nutrition and Physical Activity, 14- 42.

Sampurno. Muchammad, ka (2020). The Dangers of Social Media, Public Education and the Covid-19 Pandemic. social \& cultural syar'i , 529-542.

Soares, SM (2010). Obesity As A Social Problem ; Identifying Guidence Needs Of Nursing For Self Care. Revista De Entermagem, 18-27.

Suryadinata, D. (2019). The Effect of Physical Activity on the Risk of Obesity in Adults. The Indosia Journal of Public Health, 106-116.

Tanti Kristiana, DH (2020). The Relationship Between Sleep Patterns And Junk Food Eating Habits With The Incidence Of Obesity In Malahayati University Students In 2019. Journal of Human Care, 750761. 
Tremel. maximillan, ps (2017). Economic Burden of Obesity: A systematic Literature Review. Environmental Research and Public Health, 2-18.

Wang, xh (2017). A Systematic Review of Application and Effectiveness of Health Intervention for Obesity and Diabetes Treatment and self- Management. american for nutrition.

Widayati, A. (2019). Health Behavior: Application of Behavioral Theory for Health Promotion. Yogyakarta.

Widiantini. Winnie, Z. (2014). Physical activity, stress, and obesity in civil servants. national public health.

Wulan, S. (2019). The Effect of Brainstorming Educational Methods on Self Care in Type 2 Diabetes Mellitus Patients Kemiling Inpatient Health Center in Bandar Lampung in 2019. Nursing Science .Thesis

Yuluandari, CS (2017). Individual Psychology Approach With Acting As If Film Technique In Increasing Confidence In Adolescents Who Have Obesity: Case Study Design. Islamic Counseling Guidance, 2. 